\begin{tabular}{|l|l|}
\hline & $\begin{array}{l}\text { Jurnal Bimbingan dan Konseling Ar-Rahman } \\
\text { Volume 6, Nomor 2, Tahun } 2020 \\
\text { Tersedia Online: http://ojs.uniska.ac.id/index.php/BKA } \\
\text { e-ISSN 2477-6300 }\end{array}$ \\
\hline
\end{tabular}

\title{
PENGEMBANGAN KURIKULUM BIMBINGAN DAN KONSELING KOMPREHENSIF SMK DI ERA REVOLUSI INDUSTRI 4.0
}

\author{
Naharus Surur, Ulya Makhmudah, Agit Purwo Hartanto \\ Universitas Sebelas Maret, Surakarta, Indonesia \\ E-mail: naharus67@staff.uns.co.id
}

\begin{abstract}
ABSTRAK
Era revolusi industri 4.0 menuntut sumber daya manusia yang bermutu agar mampu bersaing dalam dunia kerja yang semakin kompetitif. Sehingga diperlukan ketrampilan dan kompetensi yang memadai dalam menghadapinya. Bimbingan dan konseling memiliki peran penting untuk membekali peserta didik, khususnya Sekolah Menengah Kejuruan (SMK) sebagai upaya membimbing peserta didik agar menjadi insan yang terampil dan kompeten dalam mencapai kemandirian pribadi, sosial, karier dan belajar. Maka dari itu, dibutuhkan pengembangan kurikulum bimbingan dan konseling komprehensif untuk peserta didik SMK pada era revolusi industri 4.0 dengan tujuan menjadi acuan bagi guru bimbingan dan konseling dalam memberikan layanan yang efektif dan efisien. Kurikulum ini akan memuat: layanan dan tujuan setiap ranah, rumusan kompetensi tingkat kelas (standar yang kompeten peserta didik yang bisa diukur), rincian kegiatan yang harus dilakukan peserta didik dan konselor dalam satuan waktu. Pengembangan kurikulum menggunakan desain penelitian dan pengembangan Borg and Gall yang sampai pada tahap uji ahli. Hasil dari pengujian yang menyatakan bahwa perhitungan yang layak untuk pembangunan pada tahap uji terbatas di penelitian tahun mendatang.
\end{abstract}

Kata Kunci: Kurikulum; Bimbingan dan Konseling; Komprehensif; Revolusi Industri 4.0

\begin{abstract}
The era of the industrial revolution 4.0 demands quality human resources to be able to compete in an increasingly competitive world of work. So that it requires adequate skills and competences in dealing with it. Guidance and counseling have an important role in equipping students, especially Vocational High Schools (SMK) as an effort to guide students to become skilled and competent individuals in achieving personal, social, career and learning independence. Therefore, it is necessary to develop a comprehensive guidance and counseling curriculum for vocational school students in the era of the industrial revolution 4.0 with the aim of being a reference for guidance and counseling teachers in providing effective and efficient services. This curriculum will contain: the services and objectives of each domain, the formulation of class level competencies (competent standards of measurable learners), details of activities that students and counselors must do in units of time. The curriculum development uses the research and development design of Borg and Gall which has reached the expert testing stage. The results of the test state that the calculations that are feasible for development at the test stage are limited to future research years.
\end{abstract}

Keywords: Curriculum; Guidance and Counseling; Comprehensive; Industrial Revolution 4.0

Dipublikasikan Oleh :

UPT Publikasi dan Pengelolaan Jurnal

Universitas Islam Kalimantan Muhammad Arsyad Al-Banjari Banjarmasin 
Naharus Surur, Ulya Makhmudah, Agit Purwo Hartanto

Jurnal Bimbingan dan Konseling Ar-Rahman

Volume 6, Nomor 2, Tahun 2020

e-ISSN 2477-6300

\section{PENDAHULUAN}

Bimbingan dan konseling diharapkan tidak hanya bersifat responsif dalam menghadapi Era Revolusi Industri 4.0, tetapi juga antisipatif dengan mengembangkan layanan bimbingan dan konseling yang menekankan pada: 1) High order thinking; 2) Out of the box thinking; 3) disruptive thinking. Ketiga orientasi tersebut dikembangkan untuk menyikapi beberapa tantangan yang dihadapi peserta didik di era revolusi industri 4.0, yaitu: perubahan nilai, perubahan privasi, serta perubahan kepercayaan.

Layanan bimbingan dan konseling, khususnya bimbingan karir bagi peserta didik di SMK tidak lagi berfokus pada cara memperoleh pekerjaan, melainkan pada cara mengembangkan kreativitas, kemampuan berpikir kritis, dan berinovasi. Peserta didik perlu dibekali soft skills yang dapat menunjang masa depan, yakni kemampuan leadership agar dapat: berkomunikasi, berkolaborasi dan terampil menggunakan perangkat teknologi (Suherman, 2018). Tujuan pembekalan tersebut agar peserta didik mampu memiliki kompetensi yang dapat bersaing di era revolusi industri 4.0.

Kurikulum bimbingan dan konseling di SMK yang telah berjalan hingga saat ini berpedoman pada Panduan Operasional Penyelenggaraan Bimbingan dan Konseling di SMK (POP BK SMK). Apabila dicermati dalam standar yang ditetapkan oleh ASCA dan apa yang telah diwujudkan dalam POP, maka terdapat substansi penting yaitu "Kurikulum Formal Bimbingan" (dalam sistem Bimbingan dan Konseling Komprehensif disebut sebagai Elemen Isi) yang tidak secara eksplisit dapat ditemukan dalam POP BK SMK.

"Through the curriculum, students are provided with skills for their personal, social, moral, cultural, spiritual development, and for exploring their feelings and beliefs (Hui, 2003). Sejalan dengan itu, pendapat lain juga mengemukakan "Comprehensive Guidance Program model, a guidance curriculum is included as one of the four programme components. It consists of life skill competencies grouped by domains and specified by grade levels delivered through structured classroom and school-wide activities" (Gysbers \& Henderson, 2012).

Pendapat tersebut menjadi rujukan bahwa aspek-aspek yang dikembangkan dalam kurikulum bimbingan dan konseling mencakup: 1) pribadi; 2) sosial; 3) moral; 4) kebudayaan; 5) perkembangan spiritual; dan 6) eksplorasi perasaan dan keyakinan peserta didik. Pendapat tersebut kemudian ditutup dengan arahan bahwa kurikulum yang dibuat harus disesuaikan dengan kebijakan daerah, serta dispesifikkan sesuai dengan tingkatan kelas.

Implementasi kurikulum bimbingan dan konseling membutuhkan keterlibatan sekolah dan administrasi sekolah. Kurikulum dirancang untuk memfasilitasi perkembangan seluruh peserta didik, atau solusi jumlah konselor yang tidak sebanding dengan jumlah peserta didik dalam memfasilitasi perkembangannya.

Kurikulum bimbingan dan konseling memberikan perhatian pada isu-isu terkini, seperti cara mencegah cyber bullying, hingga cara mempersiapkan peserta didik menghadapi revolusi industri 4.0. Handarini (2018) memaparkan strategi pengembangan potensi peserta didik pada era revolusi industri 4.0: 1) Konselor mengembangkan disruptive mindset, disruptive action, dan disruptif behavior; 2) Bekerja sama dengan berbagai pihak untuk memperoleh pemahaman tentang 'future trend'; 3) Memfasilitasi peserta didik untuk mengakses informasi tentang inovasi dan perkembangan terkini; 4) Mengidentifikasi program universitas yang berorientasi masa depan; 5) Mengubah pola bimbingan karier. Penelitian ini menggunakan strategi tersebut untuk mempersiapkan peserta didik SMK menghadapi revolusi industri 4.0.

Survei yang diisi oleh 78 responden Guru Bimbingan dan Konseling (Guru BK) SMK se Eks-Karesidenan Surakarta memperoleh hasil sebagai berikut; (1) $88 \%$ responden memiliki dokumen kurikulum bimbingan dan konseling, $12 \%$ responden tidak memiliki dokumen kurikulum bimbingan dan konseling; (2) Aspek pemahaman mengenai kurikulum mendapatkan hasil $74,4 \%$ responden memahami kurikulum, $19,2 \%$ responden kurang memahami kurikulum dan $6,4 \%$ responden sangat memahami kurikulum; (3) Sebanyak 69 dari 78 responden dengan persentase $79,5 \%$ Guru BK menyatakan telah melakukan pengembangan kurikulum bimbingan dan konseling di SMK secara mandiri; (4) Guru BK yang mengembangkan kurikulum bimbingan dan konseling di SMK secara mandiri menyebutkan tiga komponen yang sulit dikembangkan diantaranya 35 responden atau 50,7 $\%$ menganggap sulit pada pengembangan instrumen penilaian/ evaluasi, 23 responden atau $33,3 \%$ pada kegiatan pelayanan, dan 22 responden atau $31,9 \%$ pada pengembangan sumber bahan dan alat (media). Merujuk pada data tersebut maka dapat diketahui bahwa dibutuhkan adanya pengembangan kurikulum bimbingan dan konseling sebagai upaya untuk memberikan penjelasan yang lebih konkrit dan komprehensif pada layanan bimbingan dan konseling di Sekolah Menengah Kejuruan (SMK). 


\section{METODE}

Penelitian ini dimaksudkan untuk mengembangkan kurikulum Bimbingan dan Konseling untuk mempersiapkan peserta didik SMK menghadapi era revolusi industri 4.0. Oleh karena itu, metode penelitian yang digunakan dalam penelitian ini adalah penelitian pengembangan. Rancangan penelitian yang digunakan adalah rancangan Penelitian dan Pengembangan (Research and Development) dengan mengacu kepada langkah-langkah research and development dari Borg \& Gall (1979) dan Gall, Gall, \& Borg (2003).

Prosedur penelitian tersebut terbagi menjadi tiga tahap, yaitu: studi pendahuluan, pengembangan produk, dan pengujian produk. Studi pendahuluan dilakukan melalui kajian empirik untuk mengetahui permasalahan dan kebutuhan mengenai kurikulum bimbingan dan konseling pada Guru BK di SMK serta kajian secara teoritis dengan mengkaji berbagai literatur mengenai kurikulum, bimbingan dan konseling, standar kompetensi, perkembangan siswa SMK, dan hasil penelitian yang relevan.

Pada penelitian ini tahapan yang dilakukan sampai pada tahap uji ahli yang bergelar doktor serta mendalami bidang kajian pengembangan program bimbingan dan konseling komprehensif di SMK untuk menguji kelayakan draf model kurikulum

\section{HASIL DAN PEMBAHASAN}

Pengembangan prototipe kurikulum bimbingan dan konseling pada jenjang SMK yang dapat merespon kebutuhan peserta didik SMK dalam menghadapi revolusi industri 4.0 melalui 3 tahap yaitu tahap pendahuluan, tahap pengembangan produk, dan tahap pengujian produk. Tahap pendahuluan dilakukan dengan mengkaji secara teoritis mengenai kebutuhan dan permasalahan peserta didik SMK pada era revolusi industri 4.0 dan kajian mengenai pengembangan kurikulum bimbingan dan konseling khususnya pada tingkat Sekolah Menengah Kejuruan. Selanjutnya pada tahap pendahuluan juga dilakukan identifikasi mengenai kebutuhan dan permasalahan peserta didik SMK di EksKaresidenan Surakarta yang meliputi wilayah, Sukoharjo, Boyolali, Surakarta, Klaten, Wonogiri, Karanganyar, dan Sragen.

Hasil identifikasi mengenai kebutuhan dan permasalahan juga dilakukan pada Guru BK SMK yang diikuti 78 responden Guru Bimbingan dan Konseling SMK se Eks-Karesidenan Surakarta dengan memperoleh hasil sebagai berikut; (1) $88 \%$ responden memiliki dokumen kurikulum bimbingan dan konseling, 12\% responden tidak memiliki dokumen kurikulum bimbingan dan konseling; (2) Berkaitan pemahaman mengenai kurikulum mendapatkan hasil $74,4 \%$ responden memahami kurikulum, 19,2\% responden kurang memahami kurikulum, dan $6,4 \%$ responden sangat memahami kurikulum Hal tersebut mengindikasikan bahwa Guru BK di SMK se EksKaresidenan Surakarta telah memahami kurikulum bimbingan dan konseling.

Sebanyak 69 dari 78 responden dengan persentase $79,5 \%$ Guru BK menyatakan telah melakukan pengembangan kurikulum bimbingan dan konseling di SMK secara mandiri. Sebanyak 69 responden atau 79,5\% mengungkapkan bahwa pengembangan kurikulum bimbingan dan konseling yang telah disusun oleh Guru BK sudah dapat menjadi acuan dalam penyelenggaraan bimbingan dan konseling di sekolah. Guru Bk yang telah mengembangkan kurikulum secara mandiri tersebut juga mengungkapkan komponen yang sulit dikembangkan diantaranya; 35 responden atau 50,7 \% menganggap sulit pada pengembangan instrumen penilaian/ evaluasi; sebanyak 23 responden atau 33,3\% pada kegiatan pelayanan; dan 22 responden atau $31,9 \%$ pada pengembangan sumber bahan dan alat (media).

Selanjutnya Guru BK juga mengungkapkan bahwa komponen-komponen yang ada dalam kurikulum bimbingan dan konseling yang dikembangkan secara mandiri diantaranya adalah sebagai berikut; 55 responden atau $82,1 \%$ memiliki komponen tugas perkembangan/ standar kompetensi kemandirian peserta didik (SKKPD); 41 responden atau $61 \%$ memiliki komponen kompetensi; 37 responden atau 55,2\% memiliki komponen indikator; 49 responden atau $73,1 \%$ memiliki komponen tema/ topik; 48 responden atau $71,6 \%$ memiliki komponen alokasi waktu; 49 responden atau $73,1 \%$ memiliki komponen referensi/ sumber bahan; 1 responden atau 1,5\% memiliki komponen tujuan, fungsi, metode; 1 responden atau $1,5 \%$ memiliki komponen langkah-langkah kegiatan; 1 responden atau 1,5\% memiliki komponen skenario pembelajaran; dan 1 responden atau 1,5\% memiliki komponen core value sekolah. Dari data tersebut dapat disimpulkan bahwa tidak semua Guru BK mengembangkan sendiri kurikulum bimbingan dan konseling di SMK, Adapun kurikulum yang dikembangkan secara mandiri oleh Guru BK tidak semuanya memiliki komponen yang harus termuat dalam kurikulum bimbingan dan konseling. Sehingga dapat diketahui bahwa pengembangan kurikulum bimbingan dan konseling di SMK yang responsif terhadap era 
revolusi industri 4.0 menjadi sangat penting dan dibutuhkan.

Selanjutnya tahap pengembangan produk atau prototipe kurikulum bimbingan dan konseling di SMK disusun berdasarkan hasil kajian konsep dan teori mengenai layanan bimbingan dan konseling komprehensif di SMK, konsep pengembangan kurikulum berbasis kompetensi, serta kompetensi dan keterampilan yang dibutuhkan peserta didik SMK untuk menghadapi revolusi industri 4.0. Kompetensi yang dikembangkan pada kurikulum bimbingan dan konseling di SMK ini merujuk kepada beberapa lembaga, yaitu; (1) Kurikulum oleh Universitas Missouri yang mengembangkan tiga ranah utama, yaitu eksplorasi dan perencanaan karier (career planning and exploration), pengetahuan tentang diri sendiri dan orang lain (knowledge of self and others), dan perkembangan jabatan dan kependidikan (educational and vocational development); (2) Target sasaran yang lebih rinci dirumuskan oleh Texas University yang menjadi 7 ranah meliputi perkembangan harga diri (selfesteem development), motivasi untuk meraih (motivation to achieve), keefektifan antar pribadi (interpersonal effectiveness), keterampilan berkomunikasi (communication skills), keefektifan lintas budaya (cross-cultural effectiveness), keterampilan pengambilan keputusan karier (decision making skills), dan perilaku bertanggung jawab (responsible behavior); (3) American School Counselor Association (ASCA) merumuskan tiga bidang utama yang menjadi sasaran pengembangan diri peserta didik yaitu pengembangan di bidang akademik, karier, dan pribadi/ sosial (Sciarra, 2004; ASCA, 2012).

Tahap selanjutnya adalah melakukan pengujian draf awal kurikulum. Pengujian pertama adalah uji ahli. Uji ahli dilakukan pengujian kepada empat orang ahli di bidang bimbingan dan konseling yang bergelar doktor serta mendalami bidang kajian pengembangan program bimbingan dan konseling komprehensif di SMK untuk menguji kelayakan draf model kurikulum. Unsurunsur kelayakan yang diuji meliputi: kesesuaian tujuan dengan kompetensi yang akan dicapai, isi materi atau kompetensi, rincian sajian, tahap-tahap penyajian, dan penggunaan bahasa. Hasil uji ahli berupa data kualitatif. Berdasarkan uji ahli diperoleh saran untuk perbaikan kurikulum sebagaimana dipaparkan pada Tabel 1.

Berdasarkan penjabaran hasil uji ahli dari keempat validator sebagaimana tercantum pada Tabel 1, maka dapat diambil kesimpulan mengenai perbaikan Kurikulum BK di SMK yaitu bahwa suatu kurikulum perlu dikembangkan secara sistematis. Kurikulum yang dikembangkan mencakup rasional, tujuan, ruang lingkup dan penekanan, serta struktur kurikulum. Kurikulum yang baik berfokus pada personal dan sosial skill yang dibutuhkan dalam era revolusi industri 4.0 dan kebutuhan standar kompetensi peserta didik dapat mengacu K-12 dengan memadukan POPBK. Materi layanan dan alokasi waktu perlu dipertimbangkan agar materi yang disampaikan kepada siswa dapat terserap dengan baik

Pengembangan kurikulum didasarkan pada tugas-tugas perkembangan yang telah menjadi pedoman dalam menandai kemandirian peserta didik meliputi mencapai perkembangan diri sebagai remaja yang beriman dan bertakwa kepada Tuhan Yang Maha Esa; mengenal sistem etika dan nilai-nilai bagi pedoman hidup sebagai pribadi, anggota masyarakat, dan minat manusia; mengenal gambaran dan mengembangkan sikap tentang kehidupan mandiri secara emosional, sosial, dan ekonomi; mengembangkan pengetahuan dan keterampilan sesuai dengan kebutuhannya untuk mengikuti dan melanjutkan pelajaran dan/atau mempersiapkan karier serta berperan dalam kehidupan masyarakat; memantapkan nilai dan cara bertingkah laku yang dapat diterima dalam kehidupan sosial yang lebih luas; mencapai pola hubungan yang baik dengan teman sebaya dalam peranannya sebagai pria atau wanita; mempersiapkan diri, menerima dan bersikap positif serta dinamis terhadap perubahan fisik dan psikis yang terjadi pada diri untuk kehidupan yang lebih sehat; mempunyai kemandirian perilaku yang ekonomis; mengenal kemampuan, bakat, minat, serta arah kecenderungan karier dan apresiasi seni pada diri sendiri; mencapai kematangan hubungan dengan teman sebaya; dan mencapai kematangan dalam kesiapan diri untuk menikah dan hidup berkeluarga Pada penyusunannya, tugas perkembangan menjadi aspek yang perlu untuk dikembangkan. Kemudian dalam setiap aspek terdapat indikator yang menjadi penanda dalam pencaaiann aspek. Selanjutnya dalam setiap indikator dideskripsikan secara konkrit sebagai gambaran dalam pencapaian indikator. Sehingga diharapkan dengan tersusunnya kurikulum ini, guru bimbingan dan konseling dapat memberikan materi secara tepat sesuai dengan kebutuhan peserta didik SMK diera revolusi industri 4.0 
Tabel 1. Hasil Penilaian Ahli untuk Draft Kurikulum Bimbingan dan Konseling di SMK

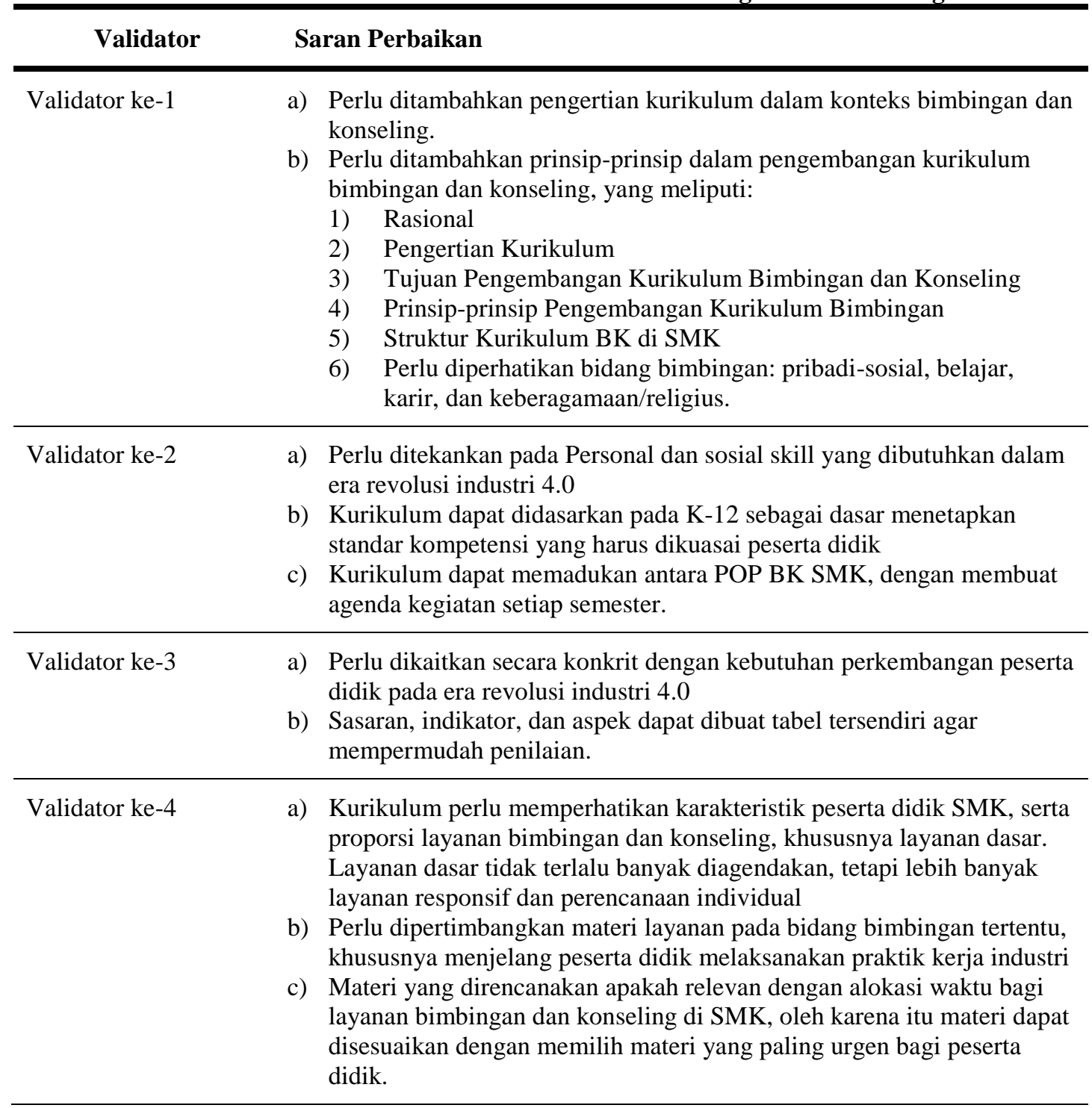

\section{PENUTUP}

Hasil dari penelitian dan pengembangan ini berupa prototipe kurikulum bimbingan dan konseling pada jenjang SMK yang dapat merespon kebutuhan peserta didik SMK dalam menghadapi revolusi industri 4.0 yang telah diuji kevalidan, keefektifan, dan kepraktisannya oleh kelompok terbatas dan siap untuk diujikan ke kelompok luas. Hasil pengembangan prototipe kurikulum bimbingan dan konseling di SMK ini diharapkan dapat dimanfaatkan oleh semua pihak dalam menyelenggarakan layanan bimbingan dan konseling di SMK. Guru BK di SMK dapat menggunakan kurikulum tersebut untuk mempersiapkan lulusan SMK yang memiliki kompetensi dan dapat bersaing di era revolusi industri 4.0 .

\section{REFERENSI}

American School Counselor Association (ASCA). (2005). ASCA national Model: A Framework for School Counseling Programs. Alexandria, VA: Author

Borg, W.R. \& Gall, M.D. (1979). Educational Research: AnIntroduction (3 ${ }^{\text {rd }}$ Ed.). New York: Longman.

Direktorat Jendral Pembinaan SMK. (2018). Tantangan Revolusi Industri 4.0 Untuk SMK. Diunduh dari https://psmk.kemdikbud.go.id pada 9 Februari 2019

Handarini, D. M. (2018). Strategi Membangun Potensi Siswa Milenial Menghadapi Era Revolusi Industri 4.0. Makalah 
Naharus Surur, Ulya Makhmudah, Agit Purwo Hartanto

Jurnal Bimbingan dan Konseling Ar-Rahman

Volume 6, Nomor 2, Tahun 2020

e-ISSN 2477-6300

disampaikan pada kegiatan Seminar

Nasional: Tantangan Generasi

Milenial di Era Revolusi Industri 4.0.

Diselenggarakan pada tanggal 21

November 2018 di Universitas Sebelas

Maret.

Hui, E.K.P. (2003). A Guidance Curriculum for Student Development: A Qualitative Study. International Journal for the Advancement of Counselling, 25, 23 September 2003.

Gysbers, N.C., \& Henderson, P. (2012). Developing \& Managing Your School Guidance \& Counseling Program. ( $5^{\text {th }}$ Ed.). Alexandria, VA: American Counseling Association.

Sciarra, D.T. (2004). School Counseling: Foundations and Contemporary Issues. Belmont, C.A: Brooks/Cole Thomson Learning.

Suherman, U. (2018). Tantangan Generasi Milenial di Era Revolusi Industri 4.0. Makalah disampaikan pada kegiatan Seminar Nasional: Tantangan Generasi Milenial di Era Revolusi Industri 4.0 yang diselenggarakan pada tanggal 21 November 2018 di Universitas Sebelas Maret.

Wibowo, M. E. (2018). Profesi Konseling Abad 21. Semarang: UNNES Press. 